\title{
The Association between Teachers' Perceptions of Learners' Social Factors and Their Academic Performance in Public Primary Schools in Hamisi Sub-County, Kenya
}

\author{
Ayodi Peter Isabwa* \\ Department of Educational Psychology, Mount Kenya University Thika, Kenya \\ *Corresponding Author \\ Ayodi Peter Isabwa
}

Article History

Received: 22.06.2020

Accepted: 01.07.2020

Published: 18.07.2020

\begin{abstract}
Formal education is subject to a confluence of factors that determine academic achievement of learners in primary schools based on teachers' perceptions. The study was conducted using descriptive survey research design in Hamisi Sub-County in western Kenya. A sample of 110 teachers was obtained using simple random sampling strategy. The data was collected using questionnaires that were self-administered by the respondents. Chisquare test was used to determine the significance of the associations between the variables ( $p>0.05)$. Data was analysed using SPSS (version 25) software. The results showed that there were significant associations between teachers' perception of learner's family economic status $(\mathrm{p}>0.351)$ and family size $(\mathrm{p}>0.066)$ and their academic performance. No significant association existed between teacher perception of learners' religious affiliation and their academic performance. Pearson's correlation tests showed no linear correlation between the academic performance and religion, family economic status and family size $(r<0.5)$. The study findings demonstrate that the way teachers' perceive the social contexts of their learners may have a great bearing on their judgement of their learners' academic performances, hence possible bias towards some of the learners based on the social perceptions they hold of the learners.
\end{abstract}

Keywords: Academic achievement; Academic Performance; Perception; Social factors.

\section{INTRODUCTION}

Teachers constitute an important school-based factor that influences student academic performance in school [1]. The role of the teacher is to ascertain that the objectives and experiences are suited to children's learning and development and challenging enough to promote their success, progress and interests in the academic fields [2]. However, there is need to understand how teachers perceive the social contexts of learners in ensuring that learning of pupils takes place appropriately. The teacher is seen as the agent in the curriculum implementation process (Ibid). It is the teacher who delivers the lesson content in line with the approved curriculum within the formal education systems. Therefore the framework that governs teachers' perspectives and knowledge of their learners and child development contributes to classroom practices and takes into account their contribution to the socio-cognitive development of children [3]. In this case, it becomes imperative to examine the association between teacher perception of the social aspects of learners and the relationship with their academic performances.

As interest in teachers' influence on their learner's increases and more studies conducted to understand the phenomenon, it should be noted that they play a very big role in positively influencing an array of their learners' short and long term outcomes [4]. Thus, the innate attribute of teachers is dependent on their attitudes and perceptions of the learners' milieu. This definitely has a heavy on those strategies that teachers use in instructing learners [5]. Education policy makers have become cognizant of the fact that school-contextual aspects are very essential in the learners' academic performance and social outcomes. Due to this, there is a need to develop policies that may result in high quality relationships between teachers and students. However no study has investigated the nexus between teacher perception of learners' social environments and contexts, thus many studies focus on learner perception of teacher attributes in exclusion of teachers'

Copyright @ 2020: This is an open-access article distributed under the terms of the Creative Commons Attribution license which permits unrestricted use, distribution, and reproduction in any medium for non commercial use (NonCommercial, or CC-BY-NC) provided the original author and source are credited. 
perceptions of the social situations of their learners in defining a better way of building teacher-learner relationships in schools [6].

In surveying available literature about teacher-student interactions, many studies have focused on the issue of how learners perceive their teachers. Building relationships between teachers and learners serves as the foundation of supporting the learning process of students and their overall development process [7,8]. Within this concept, the school as a learning institution plays a leading role in the socialization process, both formally and informally, where learning is the central objective of the existence of the school [9]. In Kenya many teachers rate their own preparation of classes and lessons positively [10]. However, there is a gap on how their perception of learners' social backgrounds impacts on this preparation. This can only be done where information exists on how teachers perceive the social contexts of learners.

While religion has been argued to develop critical thinking in learners, there is need to determine if it has an association with how teachers perceive their learners based on religion [11]. This will reflect on the general attitudes teachers have towards their learners grounded on religion of the learners and not of the teacher. While this is possible, it will help in understanding the role of religion in shaping teachers' views of their learners ability based on ethical and moral development that religion tends to instil in individuals [12], in both learners and teachers. In Kenya, a survey of available literature indicates that teacher and student perspectives on religious-based subjects have dwelt on how the subjects can be best taught. These studies are inadvertently oblivious how the religious backgrounds of learners, in the cultural contexts of the school catchment area, are associated with teacher understanding of the learners.

A report from the ministry of education showed that parents who had high levels of education and had witnessed significant career progress in their professional qualifications had a higher affinity of ensuring that their children remained in school. This is becomes pronounced when one considers vulnerable children who may be poor or have handicaps and other challenges that may affect them adversely [13]. Furthermore, in a study conducted in Rongo sub-county in south western Kenya, it was established parental level of education had an impact on the performance of learners [14]. This brings in the need to understand how teacher perception of learners' parents may impact on the learning outcomes of the learners in primary schools. Secondly, how teachers perceive parental quality that children receive from parents has not been clearly examined from a survey of available literature. For example, maltreatment of children in the United States by parents has showed that it leads to poor performance in schools and the problem cannot be handled by the school personnel alone as it requires a wider scope of stakeholders to address this issue [15]. This postulation is an example that shows there is an association between negative socialization and cognitive performance of children living in poverty, which has not been conclusively examined (Ibid). The Early Head Start (EHS) is a federally funded early childhood development program in the USA aimed at low-income families [16]. The protective effect of Early Head Start (EHS) program has been investigated in the United States of America. The study found out that children's cognitive skill performance was enhanced by psycho-social support. This is because they children recruited in the program manifested higher cognitive skill scores at three years of age than their peers who were not in EHS. Thus, there is need to have a view of teachers' perception of the social factors affecting their learners' learning outcomes.

Along the Kenyan coast in Magarini Sub-county, several factors have been attributed to the poor performance in KCPE [17]. The factors include, but not limited to, some parents having apathy for education (Ibid). This possibly can result in a scenario where such a parent, may not accord their children enough help and resources to ensure positive learning outcomes are achieved. Despite this observation, it should be noted that such factors may vary according to different regions in Kenya, due to their own unique challenges relating to schooling of children. These studies do not capture is the question of how attitude define teachers' perception of their learners' abilities in class. Home-based factors have been shown to impact on learner's outcomes [18], but how teachers perceive some of these social factors on their learners' performance is not well documented. This study, therefore, sought to determine teachers' perception of social factors of pupils and the association with academic performance of pupils in Hamisi Sub-county in western Kenya.

\section{Research Methodology}

The study was conducted using descriptive survey research design in Hamisi Sub-County in western Kenya. A sample of 110 teachers was obtained using simple random sampling strategy. The data was collected using questionnaires that were self-administered by the respondents. Chi-square test was used to determine the significance of the associations between the variables $(\mathrm{p}>0.05)$. Pearson's correlation test was used to determine the linear correlations between the variables $(r>0.5)$. Data was analysed using SPSS (version 25) software.

\section{RESULTS AND DiSCUSSION}

\section{Teachers' Perception on Family Income Levels that Influence Academic Performance of Pupils.}

Teacher perception of the learner's family economic status had a significant impact on how the teachers perceived its influence on the academic performance of their learners. According to the findings of the study, all the 
children whom the teachers perceived as coming from very poor families tended to perform poor. $5.3 \%$ of all the teachers surveyed by the study were of this view. In relation to learners who came from families that teachers perceived as being generally poor, about $13 \%$ of the teachers were of the view that they tended to perform very poor and poor respectively, while $7.9 \%$ of the teachers were of the view that their performances was average and hence fair. Only $13 \%$ and about $8 \%$ of the teachers were of the view that children from very poor backgrounds had exhibited high and very high levels academic performances. Approximately $53 \%$ of all teachers were of the view that children from very poor and generally poor families tended to perform poorly in class.

In regard to children from very poor and poor families, the reason that explains the perceptions of poor performance by their teachers is because they lack enough resources. Livumbaze and Achoka demonstrated that the socio-economic status of parents had a positive effect on their children's learning outcomes in schools [19]. This means that teachers may perceive them as poor performers because they may lack textbooks, learning resources and other utilities that may impede on their learning outcomes [20]. Secondly, research studies have shown that children from poor families may be heavily involved in household chores like fetching firewood, taking care of their siblings and helping their parents with work. This may end up limiting the duration they can concentrate on studying at home. Lack of proper nutrition is usually associated with high poverty levels and may be a factor that contributes to teachers having a negative view of the learning outcomes of children from economically disadvantaged families. Poor nutrition is an indicator of poverty and teachers' have also observed this in some children within their schools [21]. Some of the teachers interviewed in this study stated that wealthy parents usually motivated the teachers by giving them financial tokens so that they can offer extra tuition to their children. This may, in some ways, lead to teachers tending to overlook the economically disadvantaged children in favour of parents who offer them incentives to give extra-tuition to their children.

With the above explanation in mind, the study findings revealed that for those children whom the teachers' perceived as coming from families of average economic status, about $10 \%, 5 \%$ and $8 \%$ of these children tended to perform very poorly, generally poorly and average in their academic outcomes. Further, about $3 \%$ of children from these families tended to perform highly and very highly in their academic endeavours. About $8 \%$ of all the teachers were of the view that children from wealthy families tended to perform highly in class. Finally, all the teachers who were of the opinion that children from wealthy family attained very high performance constituted $3 \%$ of all the teachers surveyed. The results of the study showed that there was a significant association between the perception of teacher's view of the learner's family economic status and their academic performance in school. $\left(\chi^{2}=17.552, \mathrm{df}=16, \mathrm{p}\right.$-value $\left.=0.351\right)$. However, there was no linear correlation between the two variables $(r=0.0 .211)$. This is summarized as follows in the table below;

Table-1: Economic Status of Learners' Families and their Academic Performance

\begin{tabular}{|c|c|c|c|c|c|c|c|c|}
\hline & \multicolumn{5}{|c|}{ Level of Performance } & \multirow[t]{2}{*}{ Total } \\
\hline & & & $\begin{array}{l}\text { Very } \\
\text { Poor }\end{array}$ & Poor & Average & High & $\begin{array}{l}\text { Very } \\
\text { High } \\
\end{array}$ & \\
\hline \multirow{20}{*}{$\begin{array}{l}\text { Economic } \\
\text { Status }\end{array}$} & \multirow{4}{*}{$\begin{array}{l}\text { Very } \\
\text { Poor }\end{array}$} & Count & 0 & 6 & 0 & 0 & 0 & 6 \\
\hline & & $\%$ within Economic Status & $0.0 \%$ & $100.0 \%$ & $0.0 \%$ & $0.0 \%$ & $0.0 \%$ & $100.0 \%$ \\
\hline & & $\%$ within Level of Performance & $0.0 \%$ & $16.7 \%$ & $0.0 \%$ & $0.0 \%$ & $0.0 \%$ & $5.3 \%$ \\
\hline & & $\%$ of Total & $0.0 \%$ & $5.3 \%$ & $0.0 \%$ & $0.0 \%$ & $0.0 \%$ & $5.3 \%$ \\
\hline & \multirow{4}{*}{$\begin{array}{l}\text { Generally } \\
\text { Poor }\end{array}$} & Count & 14 & 14 & 9 & 14 & 9 & 60 \\
\hline & & $\%$ within Economic Status & $23.8 \%$ & $23.8 \%$ & $14.3 \%$ & $23.8 \%$ & $14.3 \%$ & $100.0 \%$ \\
\hline & & $\%$ within Level of Performance & $50.0 \%$ & $41.7 \%$ & $50.0 \%$ & $83.3 \%$ & $75.0 \%$ & $55.3 \%$ \\
\hline & & $\%$ of Total & $13.2 \%$ & $13.2 \%$ & $7.9 \%$ & $13.2 \%$ & $7.9 \%$ & $55.3 \%$ \\
\hline & \multirow[t]{4}{*}{ Average } & Count & 16 & 6 & 9 & 4 & 4 & 32 \\
\hline & & $\%$ within Economic Status & $36.4 \%$ & $18.2 \%$ & $27.3 \%$ & $9.1 \%$ & $9.1 \%$ & $100.0 \%$ \\
\hline & & $\%$ within Level of Performance & $40.0 \%$ & $16.7 \%$ & $50.0 \%$ & $16.7 \%$ & $25.0 \%$ & $28.9 \%$ \\
\hline & & $\%$ of Total & $10.5 \%$ & $5.3 \%$ & $7.9 \%$ & $2.6 \%$ & $2.6 \%$ & $28.9 \%$ \\
\hline & \multirow[t]{4}{*}{ Wealthy } & Count & 0 & 0 & 0 & 9 & 0 & 9 \\
\hline & & $\%$ within Economic Status & $0.0 \%$ & $0.0 \%$ & $0.0 \%$ & $100.0 \%$ & $0.0 \%$ & $100.0 \%$ \\
\hline & & $\%$ within Level of Performance & $0.0 \%$ & $0.0 \%$ & $0.0 \%$ & $25.0 \%$ & $0.0 \%$ & $7.9 \%$ \\
\hline & & $\%$ of Total & $0.0 \%$ & $0.0 \%$ & $0.0 \%$ & $7.9 \%$ & $0.0 \%$ & $7.9 \%$ \\
\hline & \multirow{4}{*}{$\begin{array}{l}\text { Very } \\
\text { Wealthy }\end{array}$} & Count & 0 & 0 & 0 & 0 & 3 & 3 \\
\hline & & $\%$ within Economic Status & $0.0 \%$ & $0.0 \%$ & $0.0 \%$ & $0.0 \%$ & $100.0 \%$ & $100.0 \%$ \\
\hline & & $\%$ within Level of Performance & $0.0 \%$ & $0.0 \%$ & $0.0 \%$ & $0.0 \%$ & $10.0 \%$ & $2.6 \%$ \\
\hline & & $\%$ of Total & $0.0 \%$ & $0.0 \%$ & $0.0 \%$ & $0.0 \%$ & $2.6 \%$ & $2.6 \%$ \\
\hline \multirow{4}{*}{\multicolumn{2}{|c|}{ Total }} & Count & 29 & 26 & 17 & 23 & 15 & 110 \\
\hline & & $\%$ within Economic Status & $26.3 \%$ & $31.6 \%$ & $15.8 \%$ & $15.8 \%$ & $10.5 \%$ & $100.0 \%$ \\
\hline & & $\%$ within Level of Performance & $100.0 \%$ & $100.0 \%$ & $\begin{array}{r}100.0 \\
\%\end{array}$ & $100.0 \%$ & $100.0 \%$ & $100.0 \%$ \\
\hline & & $\%$ of Total & $27.3 \%$ & $31.6 \%$ & $15.8 \%$ & $15.8 \%$ & $10.5 \%$ & $100.0 \%$ \\
\hline
\end{tabular}




\section{Teachers' Perception of Learners Self-Esteem and Economic Status}

The study investigated the issue of how teachers' perceived self-esteem in their learners bases on their economic status of their families. The study established hat children from families with a lower economic status tended to have generally low selfesteem which is detrimental to their learning outcomes. Economic status was shown to have an influence on the development of self-esteem, where confidence in children was more manifest as a child's family was located higher the economic ladder. According to the findings of the study, all the children who had very low esteem came from very poor families according to the perceptions of the teachers. Those who perceived children as having generally low esteem constituted $9 \%$ of the sampled population. Within this group, $50 \%$ each stated that perceive children from generally poor and middle class respectively as having generally low selfesteem. Approximately $64 \%$ of all teachers interviewed stated that their learners had moderate self-esteem. Within this group, $14.3 \%$ and $7.1 \%$ respectively stated that children from very poor and generally poor families had moderate self-esteem. In addition to this, a further $42.9 \%$ stated that children from middle families had moderate self-esteem while $21.4 \%$ and $14.3 \%$ of teachers within this group stated that children from wealthy and extremely wealthy parents tended to have moderate self-esteem respectively.

Out of all the teachers sampled in the survey, $4.5 \%$ of them were of the view that children exhibited high levels of self-esteem. Within this group, all the learners who were perceived as such by teachers all came from wealthy families. Out of 25 teachers who commented on the self-esteem of learners from very poor families, $20 \%$ of them were of the view that children from very poor families tended to exhibit very high levels of self-esteem particularly when they perform well in class. However, $13.6 \%$ of all teachers stated that learners exhibited very high levels of selfesteem. Within this group, 33\% were perceived to come from very poor families while $67 \%$ were perceived to come from extremely wealthy families. For the children from very poor families who exhibited very high levels of performance, this is possibly due to being able to score very good marks despite the economic challenges they encountered at family level which ended up giving them high levels of confidence in class. This findings correlates with Aryana's research results that showed there is a high correlation between self-esteem and learners' academic performance [22]. Consequently, both studies support the view that high self-esteem is a likely predictor of good academic performance in learners, and hence, this study concludes that teacher experience and observations of over time allow them to associate high self-esteem in learners with good academic performances in class. The study determined that there was a significant association between economic statuses of learners' family backgrounds and level of self-esteem in them as perceived by their teachers $\left(\chi^{2}=20.052, \mathrm{df}=16, \mathrm{p}\right.$-value $\left.=0.103\right)$. There was no significant linear correlation between teacher perceptions of learners' family economic statuses and self-esteem which impacts on the performance of learners in school $(r=0.35)$.

Table-2: Perceptions of Levels of Self-Esteem and Learners' Family Economic Statuses

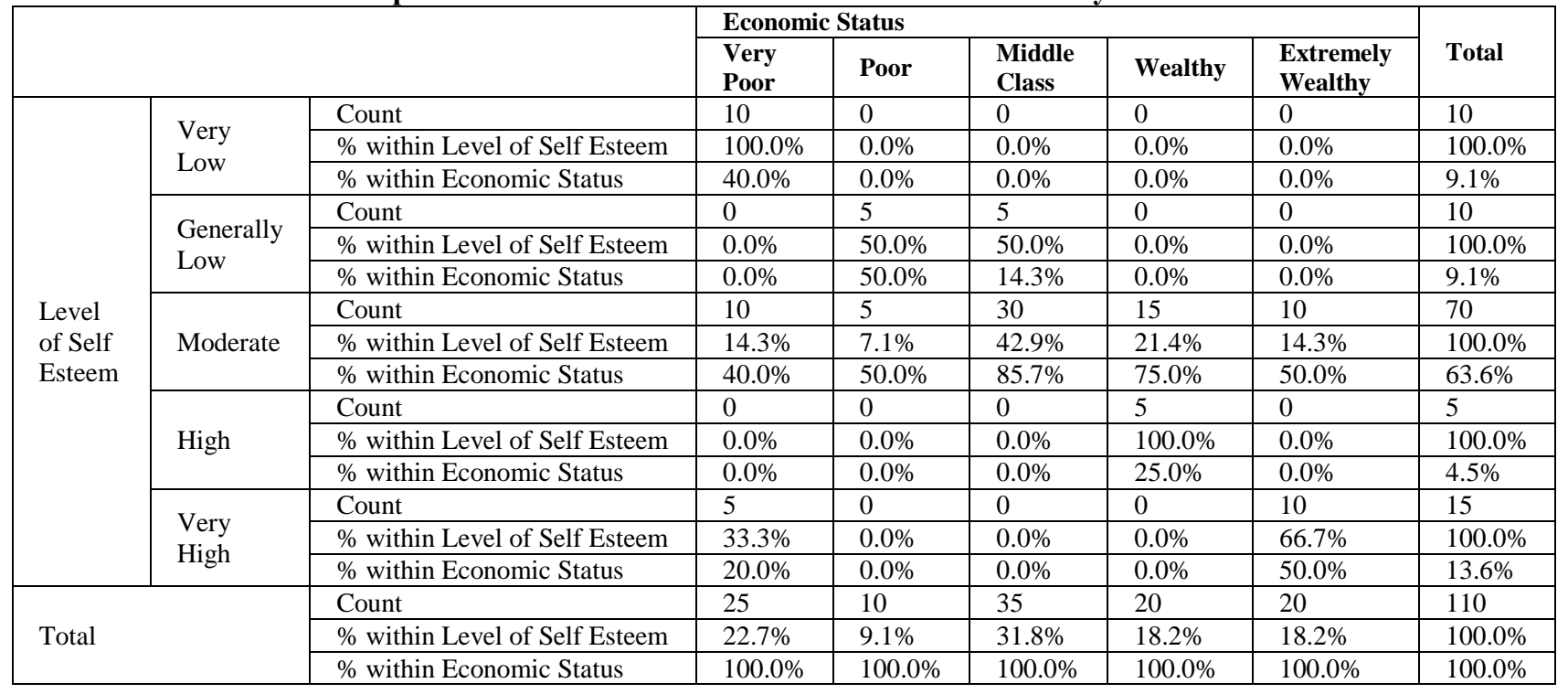

\section{Family Size and Academic Performance of Learners}

Family size was investigated on the basis of how teachers perceived their pupils' academic performances based on the size of the families they came from. The study established about $5 \%$ of all the teachers were of the view that children who had fewer siblings tended to perform very highly where they had 0 to 2 siblings. Out of the 6 teachers who were of this view, $50 \%$ each perceived that such children tended to perform high or very highly in class respectively. The explanation for this is that parents with few children tend to concentrate more on their children academic 
progress and have inclination to have higher educational and income levels. This therefore explains why teachers perceive children with fewer siblings as having a higher propensity of performing well in class.

The study found out that $10.5 \%$ of all the teachers were of the view that children with three or four siblings tended to perform well in school. For children with 5 or 6 siblings, the study found out that $23.7 \%$ of all the teachers were of the view that they tended to perform very poorly in school, $18.4 \%$ of these teachers stated that the performance was generally poor. The study established that $15.8 \%$ of all the teachers each stated that children with 5 or 6 siblings tended to have average or high performance academically in school respectively. About $8 \%$ of all teachers stated this group of children tended to have very good performance in class. $2.6 \%$ of all the teachers were of the view that children with more than 7 siblings tended to perform very poorly in class. The explanation for this is that teachers associated children with very many siblings with very poor families and, hence the perception of very poor performance by them crops up. In relation to this, the general tendency of many rural schools to perform poorly is due to high poverty levels within their catchment areas. This may inform why teachers perceive many of these large-sized families as producing children whose academic performance in school wants [23]. Furthermore, the association between household size and poverty have been shown to be positively related in developing countries which could also explain why the teachers had this perception of children from large households with many siblings [24]. There was a significant association between family size from where the learners came from and teacher perception of their performance in class $\left(\chi^{2}=\right.$ 20.052, $\mathrm{df}=12, \mathrm{p}$-value $=0.066)$. There was no significant linear correlation between family size and teacher perception of learner's performance $(\mathrm{r}=0.055)$. The table below gives a summary of this information;

Table-3: Teacher Perception of Family Size of Learners on their Academic Performance

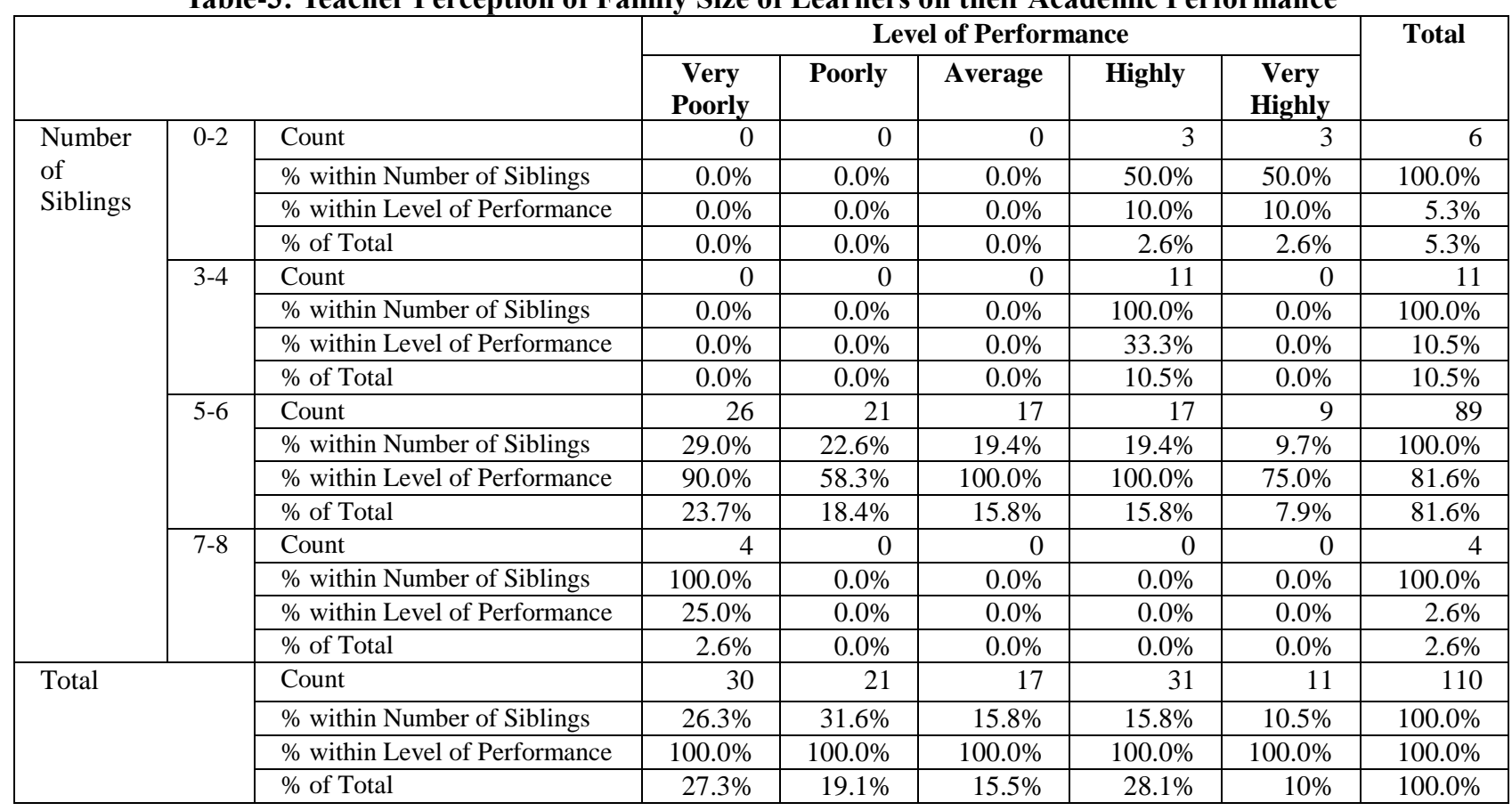

\section{Teacher Perception of Learner's Religious \\ Affiliation on their Academic Performance}

The study sought to determine if there was an association between a learner's religious affiliation and the perception of their performance in class. The study established the $78 \%$ of the teachers were of the view that a majority of their learners were Christians. This represented 86 teachers who were of that view. Within this group, $7 \%$ of them were of the view Christian learners tended to perform very poorly in class, while $12.8 \%$ were generally poor performers in class. Approximately $58 \%$ of the teachers were of the view that Christian learners were average in their academic performance. In regard to the perception of learners who had good and very good performance as perceived by their teachers, the study found out $11.6 \%$ and $10.5 \%$ of the teachers were of the view that Christian learners had good and very good performances.

In relation to Muslim learners, the study found out that 18 teachers stated that they had Muslim learners in their care. Within this group, $16.7 \%$ and $61.1 \%$ were of the view that their Muslim learners tended to perform very poorly and poorly respectively in class. Only $22 \%$ of the teachers within this group were of the view that their Muslim learners performed fairly well (average) in class. And none of them reported of these learners as good or very good performers in class. The probable explanation for these could be that many of the teachers are Christians and 
have a bias for Christian learners something which may create the perception in them of Muslim learners not performing well in class. In relation to Hindus, about $3.6 \%$ of the teachers stated that children who were Hindus tended to perform very well in class. The reason that underscores this point is the fact that many of the children who are Hindus are perceived to be either good or very good performers academically because they have the resources that make them learn. The teachers stated that Hindus tend to be rich businessmen and hence afforded learning resources for their children.
This explains why out of all the teachers who stated they had Hindu children, 50\% each stated they were either good or very good performers in class. However, the results did not show any significant association between religion and teacher perception of learner's performance in class $\left(\chi^{2}=29.88, \mathrm{df}=12, \mathrm{p}\right.$-value $=$ $0.003)$. Furthermore, there was no significant linear correlation between teacher perception of learner's performance and religious affiliation $(r=0.007)$. This is presented as follows in the table below;

Table-4: Teacher Perception of Learners' Religious Affiliation on their Academic Performance

\begin{tabular}{|c|c|c|c|c|c|c|c|c|}
\hline & & & \multicolumn{5}{|c|}{ Performance } & \multirow[t]{2}{*}{ Total } \\
\hline & & & $\begin{array}{l}\text { Very } \\
\text { Poor }\end{array}$ & Poor & Average & Good & $\begin{array}{l}\text { Very } \\
\text { Good }\end{array}$ & \\
\hline \multirow[t]{12}{*}{ Religion } & \multirow[t]{3}{*}{ Christian } & Count & 6 & 11 & 50 & 10 & 9 & 86 \\
\hline & & $\%$ within Religion & $7.0 \%$ & $12.8 \%$ & $58.1 \%$ & $11.6 \%$ & $10.5 \%$ & $100.0 \%$ \\
\hline & & $\%$ within Performance & $66.7 \%$ & $45.8 \%$ & $86.2 \%$ & $100.0 \%$ & $100.0 \%$ & $78.2 \%$ \\
\hline & \multirow[t]{3}{*}{ Muslim } & Count & 3 & 11 & 4 & 0 & 0 & 18 \\
\hline & & $\%$ within Religion & $16.7 \%$ & $61.1 \%$ & $22.2 \%$ & $0.0 \%$ & $0.0 \%$ & $100.0 \%$ \\
\hline & & $\%$ within Performance & $33.3 \%$ & $45.8 \%$ & $6.9 \%$ & $0.0 \%$ & $0.0 \%$ & $16.4 \%$ \\
\hline & \multirow[t]{3}{*}{ Hindu } & Count & 0 & 0 & 0 & 2 & 2 & 4 \\
\hline & & $\%$ within Religion & $0.0 \%$ & $0.0 \%$ & $0.0 \%$ & $50.0 \%$ & $50.0 \%$ & $100.0 \%$ \\
\hline & & $\%$ within Performance & $0.0 \%$ & $0.0 \%$ & $0.0 \%$ & $8.3 \%$ & $8.3 \%$ & $3.6 \%$ \\
\hline & \multirow{3}{*}{$\begin{array}{l}\text { African } \\
\text { Religions }\end{array}$} & Count & 2 & 0 & 0 & 0 & 0 & 2 \\
\hline & & $\%$ within Religion & $100.0 \%$ & $0.0 \%$ & $0.0 \%$ & $0.0 \%$ & $0.0 \%$ & $100.0 \%$ \\
\hline & & $\%$ within Performance & $3.4 \%$ & $0.0 \%$ & $0.0 \%$ & $0.0 \%$ & $0.0 \%$ & $1.8 \%$ \\
\hline \multirow{3}{*}{\multicolumn{2}{|c|}{ Total }} & Count & 11 & 22 & 58 & 12 & 9 & 110 \\
\hline & & $\%$ within Religion & $10 \%$ & $20 \%$ & $49.1 \%$ & $10.9 \%$ & $10.3 \%$ & $100.0 \%$ \\
\hline & & $\%$ within Performance & $100.0 \%$ & $100.0 \%$ & $100.0 \%$ & $100.0 \%$ & $100.0 \%$ & $100.0 \%$ \\
\hline
\end{tabular}

\section{REFERENCES}

1. Whittle, R. J., Telford, A., \& Benson, A. C. (2018). Teacher's Perceptions of how they Influence Student Academic Performance in VCE Physical Education. Australian Journal of Teacher Education, 43(2), Article 1. https://doi.org/10.14221/ajte.2018v43n2.1

2. Obidike, N. D., \& Enemuo, J. O. (2013). The Role of Teachers of Young Children in ensuring Developmentally Appropriate Practice in Early Childhood Education Curriculum Implementation. Journal of Emerging Trends in Educational Research and Policy Studies, 4(5), 821-826.

3. Daniels, D. H., \& Shumow, L. (2003). Child development and classroom teaching: A review of the literature and implications for educating teachers. Journal of Applied Developmental Psychology, 23(5), $495-526$. https://doi.org/10.1016/S0193-3973(02)00139-9

4. Kell, H. J. (2019). Do Teachers' Personality Traits Predict Their Performance? A Comprehensive Review of the Empirical Literature from 1990 to 2018. ETS Research Report Series, 2019(1), 1-27. https://doi.org/10.1002/ets2.12241

5. Chetty, R., Friedman, J. N., \& Rockoff, J. E. (2014). Measuring the Impacts of Teachers II: Teacher Value-Added and Student Outcomes in Adulthood. American Economic Review, 104(9), $2633-2679$. https://doi.org/10.1257/aer.104.9.2633

6. Ramberg, J., Låftman, S. B., Almquist, Y. B., \& Modin, B. (2019). School effectiveness and students' perceptions of teacher caring: A multilevel study. Improving Schools, 22(1), 55-71. https://doi.org/10.1177/1365480218764693

7. Noddings, N. (2003). Is teaching a practice? Journal of Philosophy of Education, 37, 241-252.

8. Wentzel, K. R. (2012). Teacher-student relationships and adolescent competence at school. Interpersonal Relationships in Education, 3, 19-35. https://brill.com/view/book/edcoll/9789460919398/BP000003.xml

9. Purdul, J. N., \& Mokamba, M. R. (2017). An investigation on the societal perception of teaching as a profession and an occupation in Kenya. International Journal of Education and Research, 5(8), 37-47. https://www.ijern.com/journal/2017/August-2017/04.pdf

10. Nyutu, P. N., \& Bertel, J. M. (2012). Perceptions of teacher preparation and attitudes regarding students' mental health in Kenya. Advances in School Mental Health Promotion, 5(1), 63-74. https://doi.org/10.1080/1754730X.2012.664863

11. Kowino, J. O., Agak, J. O., \& Kochung, J. E. (2012). The Role of Teaching Christian Religious Education to the Development of Critical Thinking Amongst Kenyan Secondary School Students in Kisumu East District, Kenya. International Journal of Academic Research in Progressive Education and Development, 1(2), 113-134. 
12. Nyamosi, D. (2019). The role of religious studies in enhancing moral development of secondary schools' learners in Kenya. Journal of Philosophy, Culture and Religious Study, 1(1), 20-31.

13. Ministry of Education. (2015). Basic Education Programme Rationale and Approach. www.education.go.ke/downloads/category/17-policy-documents Accessed on 23/5/2020

14. Adhanja, R. A., Nyakan, P. O., \& Yambo, J. M. O. (2016). Family-based socio-economic factors that affect students' academic performance in public schools in Rongo sub-county, Migori County, Kenya. International Journal of Research and Development Organization, 2(3), 99-122.

15. Jacob, A. B., \& Ryan, J. (2018). How life outside of a school affects student performance in school (44 No. 2). Brookings College. https://www.brookings.edu/research/how-life-outside-of-a-school-affects-student-performancein-school/

16. Head Start and Early Head Start. (2020). First Five Years Fund. https://www.ffyf.org/issues/head-start-early-headstart/ Accessed on 5/25/2020

17. Diwani, R. K. (2007). Factors affectting performace in Kcpe in Magarini Divisions of Malindi District [Thesis, University of Nairobi]. http://erepository.uonbi.ac.ke/handle/11295/18044 Accessed on 5/25/2020

18. Morumbwa, J. (2006). Factors influencing performance in enya Certificate of Primary Education (KCPE) in Nyamaiya Division, Nyamira District. [Masters Thesis, University of Nairobi]. https://irlibrary.ku.ac.ke/bitstream/handle/123456789/3011/Alex\%20Musembi\%20Kithokoo.pdf?sequence=3

19. Livumbaze, A. G., \& Achoka, J. S. K. (2016). Effects of Parents' socio-economic status on secondary school students' academic achievement in Hamisi Sub-county, Kenya. European Journal of Education Studies, 2(12), Article 0. https://oapub.org/edu/index.php/ejes/article/view/361

20. Mualuko, N. J. (2007). The issue of poverty in the provision of quality education in Kenyan secondary schools. Educational Research Review, 2(7), 157-164.

21. Oluoko-Odingo, A. A. (2009). Determinants of poverty: Lessons from Kenya. GeoJournal, 74(4), 311-331. JSTOR. https://www.jstor.org/stable/41148341

22. Aryana, M. (2010). Relationship between Self-esteem and Academic Achievement amongst Pre-University Students-SciAlert Responsive Version. Journal of Applied Sciences, 10(20), 2474-2477. https://doi.org/10.3923/jas.2010.2474.2477

23. Maiyo, J. (2015). Education and poverty correlates: A case of TransNzoia County, Kenya. International Journal of Educational Administration and Policy Studies, 7(7), 142-148.

24. Maralani, V. (2008). The Changing Relationship between Family Size and Educational Attainment over the Course of Socioeconomic Development: Evidence from Indonesia. Demography, 45(3), $693-717$. https://www.ncbi.nlm.nih.gov/pmc/articles/PMC2831397/

25. Vihiga County Education Director. (2018, June 7). Sub-counties performances in KCPE between 2013-2017 in Vihiga County [Personal communication]. 